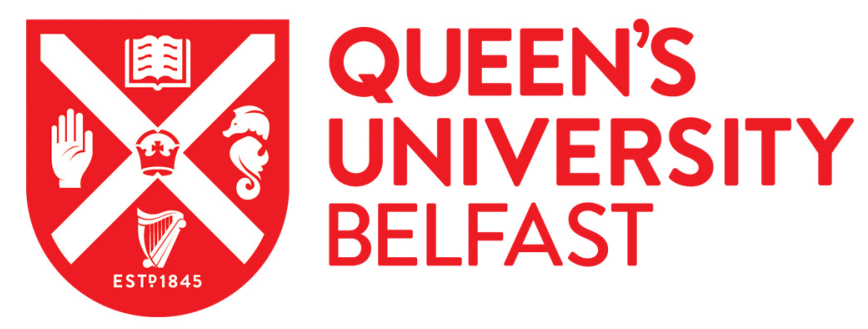

\title{
Managerialism and human rights in a post-conflict society: challenges for educational leaders in Northern Ireland
}

Donnelly, C., McAuley, C., \& Lundy, L. (2020). Managerialism and human rights in a post-conflict society: challenges for educational leaders in Northern Ireland. School Leadership and Management, 41(1-2), 117-131 . https://doi.org/10.1080/13632434.2020.1780423

Published in:

School Leadership and Management

Document Version:

Peer reviewed version

Queen's University Belfast - Research Portal:

Link to publication record in Queen's University Belfast Research Portal

Publisher rights

Copyright 2020 Informa UK Limited, trading as Taylor \& Francis Group.

This manuscript is distributed under a Creative Commons Attribution-NonCommercial-NoDerivs License

(https://creativecommons.org/licenses/by-nc-nd/4.0/), which permits distribution and reproduction for non-commercial purposes, provided the author and source are cited.

\section{General rights}

Copyright for the publications made accessible via the Queen's University Belfast Research Portal is retained by the author(s) and / or other copyright owners and it is a condition of accessing these publications that users recognise and abide by the legal requirements associated with these rights.

Take down policy

The Research Portal is Queen's institutional repository that provides access to Queen's research output. Every effort has been made to ensure that content in the Research Portal does not infringe any person's rights, or applicable UK laws. If you discover content in the Research Portal that you believe breaches copyright or violates any law, please contact openaccess@qub.ac.uk. 


\section{Title Page}

\section{Managerialism and Human Rights in a Post-Conflict Society: Challenges for Educational Leaders in Northern Ireland}

\section{Authors: Caitlin Donnelly; Clare McAuley; and Laura Lundy}

Dr. Caitlin Donnelly is a Senior Lecturer of Education in the School of Social Science Education and Social Work at Queen's University Belfast; she has undertaken research and published in the field of school governance and pedagogical practice in divided societies. Email caitlin.donnelly@qub.ac.uk

Clare McAuley is a Lecturer in the School of Education, Ulster University Coleraine. Her research interests are in the role of education in promoting social cohesion in divided societies. Email: c.mcauley@ulster.ac.uk

Professor Laura Lundy is Professor of Education Law and Children's Rights and Co-Director of the Centre for Children's Rights at Queen's University, Belfast, Northern Ireland (www.qub.ac.uk/ccr.) Her expertise is in law and human rights, with a particular focus on children's right to and in education and to participate in decision-making. • EmailL.Lundy@qub.ac.uk 


\title{
Managerialism and Human Rights in a Post-Conflict Society: Challenges for Educational \\ Leaders in Northern Ireland
}

\begin{abstract}
International human rights instruments provide a legal basis for an agreed set of human values globally. These 'values' are expected to underpin the purposes and content of education. This paper aims to explore how compliance with human rights instruments and values is balanced by educational leaders in Northern Ireland where diverse interpretations of human rights are held by the main communities and managerialist principles guide education policy making. The paper argues that whilst there is a political and policy commitment to protecting human rights in education as a means of addressing the causes of conflict, this commitment is constantly threatened by interpretations of rights in the local context and a polity underpinned by managerialist principles. It is argued that managerialist concerns around budgetary constraint and academic performance frame the work of educational leaders, yet it is in retrieving the human values which underpin rights, that the potential for educational leaders to transform society through education might be best realised.
\end{abstract}

Keywords: Human Rights; Managerialism; Educational Leadership;

\section{$\underline{\text { Main Text }}$}

\section{Introduction}

Many of the pressures facing educational leaders today resonate across the United Kingdom's four jurisdictions. These are often driven by a neoliberal ideology which prizes managerialism and has embedded a culture of 'performativity' budgetary constraint, and a focus on school standards (Ball, 2003). Thus, educational leaders in Northern Ireland face many of the same challenges as their counterparts in other jurisdictions, (see Gunter, Grimaldi, Hall, and Serpieri, 2016). However, since it is widely accepted that educational leadership is constrained by context (Clarke and O'Donoghue, 2019), what sets the role of school leaders in Northern Ireland apart from their counterparts is the unique system of educational 
governance and the school system within which their role is operationalized. The school system in Northern Ireland is underpinned by an eclectic mix of law and policy, much of which is derived from that which was applicable in England and Wales throughout long periods of direct rule from Westminster (Lundy, 1998). However, it has been tailored and adapted (some might say contorted) to produce a school system which reflects Northern Ireland's unique historical, social and political environment which has, for many years, been characterized by conflict, division, claims of discrimination and inequality. In view of this unique context, there has been ongoing discussion and debate regarding the need for Northern Ireland's education system to comply with international human rights standards (Lundy, Emerson, Lloyd, Byrne and Yohannis, 2012). Whilst international human rights instruments provide a legal basis for an agreed set of human values globally - and these 'values' are expected to underpin the purposes and content of education, this paper argues that compliance with human rights instruments and values presents significant challenges for educational leaders in NI. Any aspiration to protect human rights is in constant tension both with managerialist objectives which define education in a neoliberal context and competing human rights claims and interpretations within Northern Ireland. The paper suggests that education can achieve its social transformational goals if it reclaims human values from the grip of the managerialist discourse that currently drives educational decision making. it begins by setting out the human rights framework before examining how this framework has shaped educational administration, governance and curriculum within Northern Ireland.

\section{$\underline{\text { Main Text }}$}

\section{The International Human Rights Framework}

International human rights treaties are agreed by states with other states. The United Kingdom is the contracting party to most major international human rights treaties and, on ratification, it agrees to implement their provisions, binding itself and the three devolved jurisdictions, including Northern Ireland (Lundy et al, 2012). Support for human rights and education has a long history in the United Nations human rights treaty system, education being one of the few rights with a socio-economic character to make it into the Universal Declaration on Human Rights (UDHR). However, the most comprehensive articulation of education rights is undoubtedly the one that applies exclusively to children in the Convention on the Rights of the Child (CRC) (Hammarberg, 1998, Lundy, 2012). Article 28 of the CRC 
focuses primarily on issues of access to education, while Article 29 defines the aims of education to include high quality education, as well as tolerance, equality and respect for human rights. Together these provisions underscore the importance attributed to the role of public education in supporting key international objectives such as encouraging respect for different cultures and religions, as well as tolerance of diversity and the links between that and national and international peace and security, all of which is particularly relevant in a society like Northern Ireland emerging from conflict (Lundy, 2011).

Education rights also feature in a range of regional human rights instruments. Of particular significance is the European Convention on Human Rights (ECHR) since the United Kingdom has incorporated it into domestic law through the Human Rights Act of 1998. The ECHR states that 'no child shall be denied the right to education' and gives parents a right to have their children educated in accordance with their religious and philosophical provisions (Article 2 of the First Protocol). This means that individuals who think that their rights have been breached by public bodies, including schools, can challenge this decision in domestic courts. As a result, education leaders at all levels in the system must be human rights compliant in both the development of policy and practice.

\section{Framing Human Rights in the Context of Northern Ireland}

In Northern Ireland, human rights are very much part of the lexicon related to conflict, postconflict and peacebuilding. While a detailed exploration of human rights and the Northern Irish conflict lie outside the scope of this paper, it is important for the purposes of this paper, which predicates leadership with "context and environmental specificities" (Tibbitts, 2018, p 67), to situate human rights within the wider context of Northern Ireland - a contested and conflicted society where rights are "just another battleground for constitutional conflict" (Whitaker, 2010, p 23); a society where the divided community narratives of "them" and "us" or the "haves" and "have nots" ensures that rights are not conceived neutrally; a society where the subsequent legacy of the civil rights campaign alongside the wider claims of discrimination as underlying causes of the violent conflict makes "human rights within Northern Ireland politically and culturally difficult for unionism", with unionists tending to be "openly hostile or at least wary of human rights" (Cahill-Ripley, 2019, p 1250). Conversely, human rights discourse is much more palatable within nationalist and republican communities and, unlike their unionist counterparts, nationalist and republican politicians are 
willing to mobilise "human rights law and advocacy within their political agendas and as a tool within their communities too" (Cahill-Ripley, 2019, p 1250). Therefore, it is fair to argue that thirty years of violent conflict and allegations of inequality in Northern Ireland have resulted in a fairly sophisticated local understanding and use of international human rights law (Dickson, 1997); it is also clear that education can also be viewed as a key 'battleground' for rights as different groups seek to protect their interests and receive legitimacy from the state.

In 1998, the signing of the Good Friday / Belfast Agreement brought an end to 26 years of direct rule from Westminster and the establishment of a Northern Ireland Assembly and power-sharing Executive. As Bell (2013) notes, this political agreement founded on a consociationalist model is built around ensuring that political participation and decision making reflects group divisions - arrangements which O'Leary argues seek "to manage differences equally and justly" rather than surmounting them (2004, p 270). Moreover, in spite of the contested and politicized nature of human rights in Northern Irish society, a series of innovative human rights and equality provisions were successfully negotiated as part of the Good Friday Agreement, which endorses 'the protection and vindication of the human rights of all' and 'partnership, equality and mutual respect' (The Agreement (1998) p. 1, Declaration of Support.) The Northern Ireland Act of 1998, which implements the Agreement, contains a number of provisions intended to ensure compliance with a range of international human rights, including a proposed Bill of Rights which might have extended education rights but has never been implemented (Craig and Lundy, 2001).

Despite the fact that human rights have been recognized as fundamental to Northern Irish society, Lundy (2011) argues that there is the possibility for human rights treaties to be limited when applied to divided societies such as Northern Ireland, reflecting Merry's concept of 'vernacularisation' and the interpretation of international rights in a 'local' context (2013). However, it is Goldstein's notion of a plurality of "vernacularisations" which may more accurately reflect how human rights are interpreted in 'local' landscapes which are divided and contested such as Northern Ireland resulting in "competing understandings" (2013, p 111). As shown above, this is manifest in the different ways in which human rights are understood, framed and conceived by Northern Ireland's two main communities, illustrating the difficulties associated with the realisation of rights within Northern Ireland given the minimal-maximal interpretations of rights. Thus, not only is Northern Ireland a jurisdiction in 
which there is perceived to be a compelling need for leadership at all levels in the education system which respects and promotes human rights, it is one that demands that educational leaders deploy a range of human rights arguments in order to protect religious, linguistic and cultural rights of minority groups within the school system (Lundy, 2011).

\section{Educational Governance in Northern Ireland: Protecting a Plurality of Interests}

The administration of Northern Ireland's education system reflects its unique and complex social history. The systems and structures are designed to manage difference, recognize and preserve identity, establish a sense of belonging and protect minority groups, all which are fundamental in ensuring confidence and parity in the state school system, particularly reflecting past claims of discrimination and unequal funding for schools (see below). The Department of Education has overall responsibility for the provision of education in Northern Ireland. A single Education Authority is responsible for planning the provision of schools and must secure 'sufficient schools', that is 'sufficient in number, character and equipment to afford all pupils opportunity for education offering such variety of instruction and training as may be desirable in view of their different ages, abilities and aptitudes ${ }^{1}$ (the membership of its board of management mirrors the history and complexity of the Northern Irish education system. ${ }^{2}$ ) Mirroring the diversity of the school system, there is a range of sectoral educational bodies with a variety of obligations and powers, including dedicated bodies for: Catholic primary and (non-grammar) secondary schools (The Council for Catholic Maintained Schools); Integrated schools (The Northern Ireland Council for Integrated Education); Irish-Medium Schools (Comhairle na Gaelscolaíochta) and the most recently established body, The Controlled Schools' Support Council which is an advocacy body for the controlled schools' sector. Finally, The Northern Ireland Council for Curriculum, Examinations and Assessment has responsibility for curriculum development, as well as examinations and assessment. Whilst it could be argued that the number of bureaucratic systems and structures in place are

\footnotetext{
${ }^{1}$ Art 6 of the Education and Libraries (NI) Order, 1986 (1986 Order)

28 political members who were nominated by political parties according to the D'Hondt mechanism; 4 members representative of the interests of the Transferors (the 3 main Protestant churches) of Controlled schools; 4 members representative of the interests of the Trustees of Catholic Maintained schools; 1 member representative of the interests of Integrated schools; 1 member representative of the interests of Irish medium schools; 1 member representative of the interests of Voluntary Grammar schools; and 1 member representative of the interests of Controlled Grammar schools.
} 
disproportionate to the size of Northern Ireland's education system, Smith warns that in divided societies these function as "protective mechanisms" (2014, p 117). In other words, whilst the Department for Education has overall responsibility for providing educational leadership, policies and strategic direction, the creation of what Smith refers to as "specialised agencies", each with their own sectoral leaders and "governance arrangements that make them less susceptible to political interference" (Smith, 2014, p 117) creates a confidence that minority group interests will be secured.

\section{Separate and Integrated Schools: Issues of Governance and Leadership}

As particular interests are recognized in educational policy making they are also reflected in school governance arrangements. As indicated above, schools in Northern Ireland are almost completely religiously separated in terms of their pupil profile. Children from the Protestant community generally attend controlled (de facto state) schools (managed by the Education Authority) and Catholic pupils generally attend schools (voluntary maintained) which are owned by the Catholic Church. A small number of voluntary grammar schools are managed either by the Catholic or Protestant churches. Irish Medium schools and Integrated (mixed religion) schools enroll approximately $2 \%$ and $7 \%$ of the pupil body respectively (DE, 2019). Whilst the numbers of children attending Irish Medium schools has increased steadily in the last decade, enrolment at Integrated schools has not changed significantly. This is despite a legal duty placed on the Department of Education to provide leadership and support to 'encourage and facilitate' both Integrated ${ }^{3}$ and Irish Medium education ${ }^{4}$ and calls from the United Nations Committee on the Rights of the Child calling on the government to "actively promote" integrated education (2016).

Whilst the relationship between church and school pre-dates the partition of Ireland in 1921, the influence of the churches continued post-partition. Existing church schools were offered the opportunity to transfer their assets to the state in return for positions on the school's management committee. The Protestant Churches 'transferred', gaining a formal role in the new 'state' schools which maintained their traditional Protestant character (Akenson, 1973). In contrast, the Catholic Church was suspicious of the new Protestant/unionist dominated

\footnotetext{
${ }^{3}$ Article 64 of the Education Reform (NI) Order 1989

${ }^{4}$ Article 89 of the Education (NI) Order 1998
} 
Northern Ireland state and viewed the transfer of their schools to the state as a threat to Catholic education. Consequently, the leadership of the Catholic Church chose to retain the voluntary status of their schools and secured their autonomy by accepting a lower level of state funding (initially $65 \%$ which gradually increased to $85 \%$ ) towards the capital costs of the school. What emerged, were two separate forms of publicly funded schools - state controlled (fully funded) schools for Protestants and voluntary maintained (partially funded) schools for Catholics.

It was not until 1989, in response to increased demand from parents, that the government offered statutory and financial support to a new category of school, the Grant Maintained Integrated (GMI) school (Cumper, 1991). GMI schools have broken the tradition of church representation and nominations to the Boards of Governors are not made by the local churches. Controlled Integrated Schools (those schools which have transformed to Integrated Status allow for representation on the Board of Governors). Apart from the Integrated schools and Irish Medium schools, a significant proportion of the membership of the Boards of Governors in Northern Ireland's schools are drawn from the local clergy or their nominees. As these positions are enshrined in legislation, they afford the churches a statutory role in school leadership and governance (Lundy, 2000). It is in this way that the Churches can ensure that "the operations of schools... reflect the values and culture of each community" (Birrell and Heenan, 2013, p 777). A key way in which these values are reproduced is in the appointment and employment of teachers.

\section{Teacher Employment in Northern Ireland}

In Northern Ireland, unlike other jurisdictions, Boards of Governors can use a person's religion as a determining factor in appointments since the employment of teachers is not subject to the requirements of the Fair Employment and Treatment (NI) Order 1998 in respect of religious discrimination. Moreover, an explicit exemption for Northern Ireland in relation to the recruitment (but not promotion) of teachers is contained in the European Union's Framework Directive on Equal Treatment in Employment and Occupation 'in order to maintain a balance of opportunity in employment for teachers in Northern Ireland while furthering the reconciliation of historical divisions between the major religious 
communities'. ${ }^{5}$ Whilst this exemption applies to all schools in Northern Ireland, in practice, the exemption generally enables school leaders in Catholic schools to appoint Catholic teachers and the continuation of the exemption is robustly defended by the Catholic church. Additionally, teachers applying to work in Catholic primary schools are normally required to hold a certificate in Catholic Education and, whilst religious tests are not otherwise applied directly in the recruitment process, it appears that they may be applied indirectly through questions asking how the applicant could contribute to the 'ethos' of the school (Milliken et al, 2019). In Integrated schools, where it is necessary to ensure religious balance amongst the staff, it may be necessary for a staff member of a particular religion to be appointed. This legal exemption to use religion as a criterion in the appointment of teachers illuminates the highly complex circumstances within which educational leaders operate - a contested site where the realities of division and difference are played out on a daily basis.

\section{The Right to Separate Schools: Economic Profligacy or Sustaining the Peace?}

Whether states are under an obligation to fund diverse forms of educational provision is a complex issue in international human rights law. However, that the main school types in Northern Ireland are entitled to state-funding, as long as they can prove viability, is significant in terms of the acceptance of human rights considerations within political and educational policy in Northern Ireland. The decision to allocate equal funding demonstrates a commitment to the rights of different groups to their own educational setting and this can ensure parity of esteem particularly for minority groups - something that has been recognised as a critical factor in preserving positive relations (Halstead and McLaughlin, 2005). Yet as shown above, this financial commitment is a relatively recent development as, prior to the early 1990s, schools which were not controlled by the state (mainly Catholic schools) could only receive up to $85 \%$ of their capital costs. However, the government's decision to provide 100\% funding to Integrated schools in 1989 allowed the Catholic Church to argue that the provision of full funding for Integrated schools discriminated against the Catholic community (McGrath, 2000). Hence in 1993, in the wake of research which indicated that children attending Catholic schools had lower levels of attainment which could be attributed in part to the reduced funding for capital expenditure (Cormack et al., 1991), legislation was enacted

\footnotetext{
${ }^{5}$ Council Directive 2000/78/EC Article 15
} 
which allowed Catholic schools to opt for full capital costs if they agreed to appoint an additional governor from the Department of Education. ${ }^{6}$

Equal funding for a diverse range of schools has been secured through long-standing campaigns by leaders of Catholic, Integrated and more latterly the Irish Medium sector which has drawn heavily on arguments about equality and minority rights. This 'levelling up' of funding demonstrates a political commitment to provide financial resources which extends beyond that available to similar schools in other jurisdictions and is inextricably linked to Northern Ireland's particular social and political context and the advocacy around human rights and equality. Indeed, the leaders of the Irish Medium and Integrated school sectors have shown that they are prepared to employ legal action drawing on domestic and international human rights frameworks to secure their growth and recognition. Recent legal cases brought forward and won by the Integrated and Irish Medium sectors in terms of access to schools have indicated that it is not legally acceptable to protect the status quo given the Department of Education's duties to 'encourage and facilitate' both Integrated and Irish Medium education. However, whilst this rights-based approach to educational provision might be regarded as laudable, the stringent economic climate and what Murtagh and Shirlow describe as a "constantly expanding neoliberal model of governance" $(2012, p 46)$ has the potential to undermine the arguments put forward. Indeed it might be argued that neoliberalism presents a fundamental challenge to the preservation of human rights; Lynch $(2014$, p 4) explains that managerialism, as the organisational manifestation of neoliberalism, recasts educational and social problems "..... as management issues that new and more efficient managerial regimes can resolve"; hence human well-being is not determined in social and emotional terms but rather is framed as inextricably linked to the pursuit of entrepreneurialism and the free market. In the public sector this means that organizations are focused on cost consciousness, budgetary constraint and performance against predetermined targets.

The tension between neoliberal perspectives and human rights is perhaps best exemplified in recurring arguments around the cost of separate schools, which is frequently cited as a reason

\footnotetext{
${ }^{6}$ Education (NI) Order 1993, article 28
} 
for educating all children together. This "duplication of provision" argument is gaining momentum given the continued surplus of school places across Northern Ireland (Roulston and Hasson, 2019, p 4). Hence, in 2010, the former First Minister of Northern Ireland Peter Robinson called for an end to the government funding of Catholic schools as part of a push towards a mixed education system (Belfast Telegraph, 2010). Whilst this statement might be interpreted as a benign, common-sense approach to resourcing schools in a financially straitened context, it belies the important role that Catholic schools have traditionally occupied in securing the Catholic community's sense of legitimacy in a contested state. Moreover, the 2020 'New Decade New Approach' Agreement (which prompted a return to power-sharing in Northern Ireland) included a declaration that the diversity of school types is "not sustainable", suggesting perhaps that Robinson's perspective has gained further political traction.

Yet, and somewhat paradoxically, although diversity in school types has been deemed financially unsustainable by the former First Minister and the most recent political Agreement, no such bold declaration has been made in relation to the continuing operation of an academically selective system of education at post-primary level - a system which has consistently been criticized as being in breach of the United Kingdom's human rights obligations by the United Nations Committee on the Rights of the Child (UN, 2016; Lundy et al, 2012). Public views on selection are polarised and these divisions are echoed in the positions adopted by the political parties, with the unionist political parties supporting the retention of academic selection, while the nationalist parties generally advocate its abolition and all-ability schools.

Thus far, this paper has explored how educational leaders negotiate and traverse complex governance and "institutional structures (that) reflect and replicate the political, social and cultural divisions within broader society" (Smith, 2014, p 118). This is, as Clarke and O'Donoghue argue, the context that "gives (educational leadership) its meaning" (2019, p 495). It suggests the invidious position occupied by educational and school leaders who are charged with balancing a number of competing interests; yet it also reveals the strength of a rights-based approach in protecting a plurality of interests in a divided society and thereby addressing (in part) the causes of conflict. These protections are constantly threatened by local vernacularisations of rights and neoliberal approaches to education (framed as 'common 
sense) which emphasize rationalisation and budgetary constraint as key principles of educational management. Such tensions are also evident at the school level.

\section{Addressing the Causes and Consequences of Conflict: The Importance of School Leaders}

Article 28 of the CRC which focuses on access to education, and Article 29 which defines the aims of education in terms of tolerance, equality and respect for human rights place certain obligations on school leaders. Specifically, school leaders must ensure that pupils are afforded opportunities to access education that is consistent with their parents' identity and beliefs whilst also learning to practice tolerance and respect for the beliefs of others. Education policy in Northern Ireland has responded to these obligations in several ways. Firstly, and as noted above, through publicly funding a range of schools to reflect the varied beliefs of parents. Secondly, it has offered opportunities for inter-group contact for children whose parents have chosen separate schools (primarily through Shared Education). Finally, it provides opportunities for young people to learn about human rights and to understand 'the past' so that they can respect the views of others (primarily through the citizenship curriculum).

\section{Shared Education}

Since 2016 a legal duty has been placed on the Department of Education to ensure that schools work collaboratively to create opportunities for children to engage in contact with pupils in a school from another faith/cultural tradition. Shared Education has thus become an important mechanism through which young people (often for the first time) have an opportunity to meet with those from another community background. However, as Lundy et al (2012) acknowledge, the legislation and guidance does not take account of the implications of cross-community collaboration on the child or young person's right to cultural identity and freedom of religion within a school ethos that may not align with their own or a parent's religious and cultural values. There appears to be at least two inherent dilemmas with which school leaders need to grapple: Firstly, to comply with the values and ethos of their sector and to reflect parental wishes, leaders will feel compelled to ensure that their schools display the symbols associated with their religious and cultural ethos. Yet Shared Education also demands that the display of symbols and practices to reflect the school ethos does not alienate or offend those from a different tradition who come to take classes at that school 
(Donnelly \& Gallagher, 2008). Secondly, Shared Education slots neatly into a polity that is motivated by managerialist values, where individuals are framed as perpetual consumers and where rationalisation and financial control is a key imperative (Hughes et al, 2016). Hence it offers opportunities for subjects to be shared between schools so as to extend choice, allow schools to make savings and share professional expertise. Yet how leaders ensure that young people who opt out of 'sharing education' on the grounds of identity and beliefs are able to access the full suite of curricular options to which they are entitled is unclear. Shared Education thus presents school leaders with the seemingly insurmountable challenge of attempting to improve relationships between deeply fractured communities within an educational policy context that demotes the value of human relationships as an educational objective.

\section{Curriculum}

Human Rights Education (HRE) is afforded considerable importance in the citizenship curriculum in Northern Ireland. This reflects international imperatives which oblige states to commit to HRE and a growing body of research which suggests that HRE has a critical role to play in encouraging young people to harness their critical capacities. HRE also offers a useful political framework to explain the factors that cause and sustain conflict whilst providing a space in the curriculum to open discussions with pupils on societal transformation (Davies, 2005; McEvoy, 2007; Tibbitts, 2018). Reference to human rights is made in both primary and post primary school curricula in Northern Ireland. Personal Development Mutual Understanding (PDMU) (primary) and Local and Global Citizenship (LGC) (post primary) are the main curricular vehicles for teaching about human rights. At Key Stage 2 (age 8-11) reference is made to 'developing knowledge, understanding and skills in human rights and social responsibility'. At Key Stage 3 (age 11-14) LGC presents as a core theme: 'Human Rights and Social Responsibilities' which has specific regard to maintaining human rights standards, investigating human rights principles, balancing and limiting rights and investigating examples of infringement of rights. At Key Stage 4 (age 14-16) students can either study LGC where they have the opportunity to explore 'rights and social responsibilities' or, as is often the case, many students choose to take a GCSE in Learning for Life and Work where some reference is made to human rights instruments. 
Despite the rhetorical importance afforded to HRE within the citizenship curriculum, the education of teachers and school leaders to create a human rights culture where young people have an opportunity to learn in, through and about human rights as advocated in the UDHR is enervated by the absence of any legal obligation on schools to do so. Indeed, McEvoy (2007) argues that the potential impact of HRE is diluted by several elements contained within the policy text. These include the presentation of HRE as a set of values that inform citizenship education rather than a legal entitlement for young people to learn about the human rights instruments. Human rights instruments are generally presented as exemplars or their use is advised as good practice. The lack of any statutory obligation on teachers to refer to the human rights instruments therefore impedes the potential of young people to learn about human rights (Lundy, et al 2012). Relatedly, the programme of in-service teacher training, introduced to support the 'roll out' of citizenship education and which was widely commended as being comprehensive and well-resourced (Arlow, 2012) was primarily concerned with how to use active pedagogies to teach citizenship and human rights and did not afford educational leaders a substantive knowledge of the conceptual basis for human rights (McEvoy 2007). This is important for three reasons: firstly, it creates the potential for variance in human rights education across schools as leaders' personal 'vernacularisations' of rights will shape and determine how they engage with the concept (Worden \& Smith, ${ }^{\circledR} 2017$ ); secondly and relatedly, many staff in schools often feel threatened by children's rights. There is thus an inherent responsibility on school leaders to ensure that their staff understand that "children's rights are not a zero sum game in which teachers inevitably lose out" but in order to do so they must themselves have the personal disposition and knowledge (Freeman, 1992, p 407); and thirdly, in a culture inspired by neoliberal values, citizenship education remains a 'low status' subject compared to those with a more obvious economic appeal. Hence, the opportunity for teachers to fully engage students' interest and build understandings of conflict and the past is inevitably constrained as efforts are directed at curricular subjects that are deemed more economically expedient (Reilly and Niens, 2014; O’Connor-Bones et al, 2019; Muff, 2019).

In summary then the potential of HRE and Shared Education to harness students' knowledge of the conflict and improve their capacity to build cross-group relations depends on school 
leaders and their capacity to find equilibrium between the competing values of human rights, managerialism and their personal 'vernacularisation' of rights.

\section{Discussion and Conclusion}

Tensions between ideological positions on the purpose of education are often most pronounced in countries in conflict where the role of education in addressing the causes and consequences of conflict often co-exist with managerialist perspectives on education which place a priority on budgetary constraint and academic standards (Davies, 2005). Educational leaders play a key role at every policy tier in balancing these tensions. Drawing on examples from Northern Ireland this paper has shown that local 'vernacularisations' of rights can intersect with neoliberal sentiments to limit the potential of rights frameworks to address the causes and symptoms of conflict. The paper has highlighted several issues for educational leaders in Northern Ireland that are likely to have resonance for other divided societies.

Firstly, it shows that whilst the complex administrative system of education in Northern Ireland is frequently framed as socially divisive and expensive - 'common sense' concerns of a neoliberal state- it ensures the preservation of the plurality of interests in education. This offers legal protection to minority groups in a contested state and contributes to sustaining peace. Whilst this argument is rarely rehearsed it is recognised as a critical feature of educational and political leadership in Northern Ireland and has been instrumental in addressing (in part) the grievances of minority communities (Smith, 2014).

Secondly, it suggests that the political commitment to protecting rights at the macro level is not entirely reflected at the meso tier. This is exemplified in the notable dilution of human rights legal obligations in the policy text for citizenship education. Hence any statutory obligation to teach citizenship with reference to human rights instruments has been relegated in favour of a more palatable curricular text that replaces statutory obligations to use human rights instruments in teaching with exemplars of 'good practice' and advice (McEvoy, 2007). Moreover, and further reflecting the persuasive power of the neoliberal and managerialist discourse, the position of the citizenship curriculum at the micro level in schools is weakened as subjects with a notably more academic orientation are accorded more space and status (Muff, 2019). School leaders are left in a difficult position of balancing requirements to create spaces for building intergroup relationships based on tolerance and respect both through the 
citizenship curriculum and through initiatives such as Shared Education within a political and policy context that instinctively relegates the value of relationships in favour of academic performance.

Finally, whilst neoliberal values are arguably more intuitively appealing than human rights as an organising principle for educational systems, it might be suggested that it is in lending greater coherence and emphasis to the values of humanity which lie at the heart of the human rights framework, that aspirations of academic and social improvement can be best fulfilled. Educational leaders have the agency to reclaim education from the grip of neoliberalist ideologies and reorient it towards human value, including human rights (Patrick, 2013). In conflict societies such reclamation seems particularly apposite yet it will necessitate open debate amongst political and educational leaders around the purpose of education. In Northern Ireland this will demand a shift from the cultural silence that pervades discussions of conflict and rights towards a more open and critical reflection on what human rights mean in context and how they can be realised within educational settings. Without open debate and a commitment to retrieve the human values which underpin rights the potential to transform society through education is inherently compromised.

Declaration of interest statement: The authors have no interests to declare in respect of the arguments rehearsed in this paper. 


\section{References}

Akenson, D.H. (1973) Education and Enmity. Newton Abbott: David and Charles.

Arlow, M. (2012) 'Education for Local and Global Citizenship: The Northern Ireland Experience', in Education for Global Citizenship, Doha, Qatar: Education Above All, p 82-91.

Ball, S. J. (2003) 'The Teacher's Soul and the Terrors of Performativity', Journal of Education Policy, 18(2), p 215-228.

Bell, C. (2013) 'Power-sharing and Human Rights Law', The International Journal of Human Rights, 17(2), p 204-237.

Birrell, D. and Heenan, D. (2013) 'Policy Style and Governing without Consensus: Devolution and Education Policy in Northern Ireland', Social Policy and Administration, 47 (7), p 765-782.

Cahill-Ripley, A. (2012) 'Exploring the Local: Vernacularizing Economic and Social Rights for Peacebuilding within the Protestant/Unionist Borderland Community in Northern Ireland', The International Journal of Human Rights, 23(8), p 1248-1275.

Clarke, S., and O'Donoghue, T. (2019) 'School Leadership and Borderlands: Crossing into Unchartered Territory', International Journal of Leadership in Education, 22(4), p 486-497.

Cormack, R.J., Gallagher, A.M., and Osborne, R.D. (1991) 'Religious Affiliation and Educational Attainment in Northern Ireland: The Financing of Schools in Northern Ireland', in Annex E of the (1991) Sixteenth Report of the Standing Advisory Commission on Human Rights (19901991), London, HMSO, p 117-212.

Craig, E. and L. Lundy (2001) 'Education Rights in the Bill of Rights', Northern Ireland Legal Quarterly, 52, p 325-334.

Cumper, P. (1991) 'Parent Power', Education and the Law, 3(1), p 27-33.

Davies, L. (2005) 'Evaluating the Link between Conflict and Education', Journal of Peacebuilding and Development, 2(2), p 42-58. 
Department of Education for Northern Ireland (2020) Annual Enrolments at Schools and in Funded Pre-school Education in Northern Ireland, 2019-2020. https://www.educationni.gov.uk/publications/school-enrolments-201920-statistical-bulletins

Dickson, B. 'Northern Ireland and the European Convention', in. Dickson, B. (1997) (Ed), Human Rights and the European Convention, London, Sweet and Maxwell.

Donnelly, C and Gallagher, T (2008) School Collaboration in Northern Ireland: Opportunities for Reconciliation? Belfast: Queen's University.

Freeman, M.D. (1992) 'Taking Children's Rights More Seriously', International Journal of Law, Policy and the Family, 6(1), p 52-71.

Goldstein, D.M. (2013) 'Whose Vernacular? Translating Human Rights in Local Contexts', in M. Goodale (Ed) Human Rights at the Crossroads. New York, NY: Oxford University Press.

Gunter, H.M., Grimaldi, E., Hall, D. and Serpieri, R. (2016) (Eds) New Public Management and the Reform of Education: European Lessons for Policy and Practice. Routledge.

Halstead, J. M and McLaughlin, T (2005) 'Are Faith Schools Divisive?', in: Faith Schools: Consensus or Conflict? Routledge, p 61-73.

Hammarberg, T. (1998) A School for Children with Rights: The Significance of the United Nations Convention on the Rights of the Child for Modern Education Policy. UNICEF Innocenti Research Centre, Florence, Italy

Hughes, J., Donnelly, C., Leitch, R., \& Burns, S. (2016) 'Caught in the Conundrum: Neoliberalism and Education in Post-Conflict Northern Ireland - Exploring Shared Education', Policy Futures in Education, 14(8), p 1091-1100.

Lundy, L. (2000) Educational Law and Legislation. SLS Legal Publications (NI).

Lundy, L. (1998) 'From Act to Order: The Metamorphosis of Education Legislation', Liverpool Law Review, 20(1), p 63-93.

Lundy, L. (2011) 'Mainstreaming Children's Rights in, to and through Education in a Society Emerging from Conflict', in Children's Rights: Progress and Perspectives, p 191-217: Brill. 
Lundy, L. (2012) 'Children's Rights and Educational Policy in Europe: The Implementation of the United Nations Convention on the Rights of the Child', Oxford Review of Education, 38(4) p 393-411.

Lundy, L., Emerson, L., Lloyd, K., Byrne, B., \& Yohanis, J. (2012) Education Reform in Northern Ireland: A Human Rights Review. Northern Ireland Human Rights Commission.

Lynch, K. (2014) 'New Managerialism: The Impact on Education', Concept 5(3), p 1-11.

McEvoy, L. (2007) 'Beneath the Rhetoric: Policy Approximation and Citizenship Education in Northern Ireland', Education, Citizenship and Social Justice, 2(2), p 135-157.

McGrath, M. (2000) The Catholic Church and Catholic Schools in Northern Ireland: The Price of Faith. Dublin: Irish Academic Press

Merry, S.E. (2013) 'Monitoring and the Question of Indicators', in M. Goodale (Ed) Human Rights at the Crossroads. New York, NY: Oxford University Press.

Milliken, M., Bates, J. \& Smith, A. (2019) 'Education Policies and Teacher Deployment in Northern Ireland: Ethnic Separation, Cultural Encapsulation and Community Cross-over', British Journal of Educational Studies, p 1-22.

Muff, A. (2019) Citizenship Education and Identity: A Comparative Study Across Different Schools in Northern Ireland and Israel. Unpublished PhD Thesis; Queen's University Belfast.

Murtagh, B., and Shirlow, P. (2012) 'Devolution and the Politics of Development in Northern Ireland', Environment and Planning C: Government and Policy, 30(1), p 46-61.

O'Leary, B. (2004) 'The Nature of the Agreement', in J. McGarry and B. O' Leary (Eds) The Northern Ireland Conflict: Consociational Engagements, p 260-293. Oxford: Oxford University Press.

O'Connor Bones, U., Worden, E. A., Bates, J., and Gstrein, V. (2019) 'Lessons Learned from 10 Years of Citizenship Education in Northern Ireland: A Critical Analysis of Curriculum Change', The Curriculum Journal. https://doi.org/10.1002/curj.2

Patrick, F. (2013) 'Neoliberalism, the Knowledge Economy, and the Learner: Challenging the 
Inevitability of the Commodified Self as an Outcome of Education', International Scholarly Research Notices Education, p 1-8.

Reilly, J., and Niens, U. (2014) 'Global Citizenship as Education for Peacebuilding in a Divided Society: Structural and Contextual Constraints on the Development of Critical Dialogic Discourse in Schools', Compare, 44(53), p 53-76.

Belfast Telegraph (October 16, 2010) Peter Robinson Calls for end of School Segregation

Roulston, S. and Hansson, U. (2019) 'Kicking the Can Down the Road? Educational Solutions to the Challenges of Divided Societies: A Northern Ireland Case Study', Discourse: Studies in the Cultural Politics of Education, $\mathrm{p}$ 1-14.

Smith, A. (2014) 'Contemporary Challenges for Education in Conflict Affected Countries', Journal of International and Comparative Education, 3(1) p 113-125.

Tibbitts, F. L. (2018) 'Human Rights Education: The Good Surf and Reclaiming Human Rights', Netherlands Quarterly of Human Rights, 36(1), p 64 -74.

United Nations, UN Committee on the Rights of the Child (2016) Consideration of Reports submitted by States Parties under Art. 44 of the Convention: United Kingdom of Great Britain and Northern Ireland (Geneva, United Nations).

Whitaker, R. (2010) 'Debating Rights in the New Northern Ireland', Irish Political Studies, 25(1), p 23-45.

Worden, E. A., and Smith, A. (2017) 'Teaching for Democracy in the Absence of Transitional Justice: The Case of Northern Ireland', Comparative Education, 53(3), p 379-395.

\section{Legislation cited}

Education Reform (NI) Order 1989.

Education and Libraries (NI) Order 1993.

Education (NI) Order 1998.

Fair Employment and Treatment (NI) Order 1998 
International Treaties and Conventions

Universal Declaration on Human Rights (1948), Articles 26

European Convention on Human Rights and Fundamental Freedoms (1950), Article 14, Article 2 of the First Protocol.

United Nations Convention on the Rights of the Child (1989). 